\title{
A THEORETICAL MODEL OF PREPARATION OF FUTURE MILITARY PILOTS FOR COMBAT FLIGHTS
}

\author{
Roman Nevzorov \\ Candidate of Pedagogical Sciences, Deputy Head of the Department of Flight Operation \\ and Air Warfare, Ivan Kozhedub Kharkiv National Air Force University, Ukraine \\ e-mail: roman.nevzorov1970@gmail.com,orcid.org/0000-0003-1496-2465
}

\section{Summary}

The purpose of the article is to present to the scientific community the principles of the author's theoretical model of training of future pilots for combat flights. As a new direction in military pedagogy, the process is believed to be significant for training of future military pilots in the practice of higher education military institutions in Ukraine. Its pedagogical simulation was conducted for the first time. The author's model is believed to be peculiar because it considers the military education specifics and clear orientation on professional combat engagement of military aviation specialists. Components of the author's model are described herein, and its schematic graph is offered for clarity. Gaps and inconsistencies in the training of future military pilots between actual requirements for modern military specialists, the theory and practice of this process are specified. Since the simulation study of the issue is conducted for the first time, the author points that the proposed model is to be specified and adjusted, and theoretical provisions and preliminary conclusions to be experimentally verified. The research was conducted for the doctoral thesis at the two leading higher education aviation institutions in Ukraine.

Keywords: future military pilot, professional training, combat flight, simulation study in pedagogy, simulation pedagogical model, higher education military institution.

\section{DOI: https://doi.org/10.23856/3862}

\section{Introduction}

In recent years, strengthening and modernization of the Armed Forces of Ukraine, including the Air Force, has been implicitly considered as one of the key factors to preserve national statehood and territorial integrity. Under the current tense geopolitical situation around Ukraine, the training of highly professional military personnel according to leading international and NATO standards seems to be especially important.

Previous researches on the training of military pilots at HEMIs were conducted mainly within aviation psychology and pedagogy, without consideration of the military education specifics and the military didactics peculiarities. Preparation of future military pilots for combat flights has never been studied in the military pedagogical science as a separate pedagogical research subject, and therefore is believed to be a new promising issue.

Currently a significant gap is observed between actual objective requirements of scientific and technical development to military pilots' core competencies, the level of scientific and theoretical support for their training and their actual practice at domestic HEMIs. A holistic pedagogical system of effective professional training of military pilots for combat flights has not been formed yet. The system design and implementation should begin with its theoretical model to be created. 
The goal of the research is to try to outline for the first time the contours of the theoretical model of training of future military pilots for combat flights based on the simulation study method. Tactical tasks in the goal achievement are to identify and justify the model components and the internal links between them.

\section{Professional training of future military pilots}

In general pedagogy, traditionally the concept of "training" is inextricably connected with two components - the process of training of future professionals to vocational activity and the process outcome, expressed in the young professionals' readiness to this activity. Extrapolating this approach to military education for future pilots, we propose to consider the training of future tactical aircraft pilots as a specially organized process of training and education of future military pilots at multidisciplinary HEMIs with scientific, pedagogical, organizational and tactical specifics, and resulting in their readiness for vocational military activity due to the formation of the system of knowledge, skills and abilities to perform combat tasks in the air (survival instinct) as the art of training and performing combat flights.

Studying at HEMIs is a component of professional training of military specialists. An analysis of pedagogical sources allows to state that the modern pedagogical interpretation of professional training reduces it to two key points - the formation of professionally significant knowledge, skills and abilities of the future specialist during educational activities (professional education) and the result of this activity, expressed as core competencies with the mandatory psychological readiness for the future profession. In turn, vocational training is indicated to be a form and a tool for the vocational education: during this process, didactic goals are to be determined, pedagogical goals to be set, learning to be modeled, teaching methods and ways to be clarified, specified and correlated, a pedagogical result to be formed. At the same time, it is able to act as an indicator of the successful training and readiness for vocational activity. Based on the above, the training of future tactical aircraft pilots should be considered as a didactic system of organizational, educational and specific methodological measures aimed to train and educate the personality of a military pilot capable of performing any combat missions and resulted in his professional and psychological readiness for successful vocational activity (Nevzorov, 2020). This interpretation will be the initial point in development of the appropriate theoretical model.

\section{Combat flight as an object of pedagogical modeling}

Combat flight is not actually a pedagogical category. In order to achieve the goals of the author's doctoral thesis research (and the article as a publication of provisions thereof), we borrowed it from the military science. In the theory of military aviation and current administrative documents of the Ministry of Defense of Ukraine, it is defined as a flight to perform a combat mission (assigned task). In the military-pedagogical study, a combat flight appears as the basis of a military pilot's professional activity, its most important component to demonstrate the level of training, physical and psychological readiness, ability for improvement and moral endurance. As for training of future military tactical aircraft pilots, we propose to consider it as the main type of vocational activity of military pilots, aimed to perform combat missions, and readiness (physical, psychological, technical) - as a key competence indicator of the educational system to ensure quality for training of future tactical aircraft pilots to perform combat missions. In this sense, this category is used to create a theoretical model of training of future military pilots for combat flights. 


\section{Principals of the author's theoretical model}

A model in science and philosophy is traditionally considered broadly as "a universal tool of conscious perception of reality, especially in the vocational activity" (Osadchyi, 2017: 145) and narrowly as a holistic reflection of a real object in perfect shape. The method of pedagogical modeling or simulation study in pedagogy allows to learn various pedagogical phenomena, processes, constructs, etc. by reproducing their characteristics on specially built theoretical models. The classical definition of the model as a method of pedagogical cognition was offered by V.A. Shtoff: "A model is a mentally imagined or materially realized system, which, reflecting or reproducing a research object, is able to replace it so that its study will give us new information about this object" (Shtoff, 1966: 12).

Given that the process of training of future military pilots for combat flights has not been studied yet as a separate construct in military pedagogy, it seems appropriate and scientifically justified, in our opinion, to study it by developing an appropriate theoretical model.

In pedagogical science, models are known to be divided into educational and research ones. The latter provide scientific search and contribute to the study of pedagogical objects. The offered model should be related to this group. Research models, in turn, are divided into ascertaining (conceptual), research and simulation ones. Considering the subject of our research, which is essentially a specific type of educational process, in order to study the influence of external factors on the system behavior, we chose the simulation type of the model, designed to reproduce essential characteristics of its behavior.

Thus, we propose to outline the basics of the pedagogical research simulation model, aimed to substantiate scientifically and theoretically the modern, effective and flexible system to ensure quality for training of military aviation personnel for the needs of the Armed Forces of Ukraine, taking into consideration the level of development and best military aviation experience, in peace and war.

The model envisages the formation of the future Air Force pilot's personality at domestic HEMIs basing on the holistic system of professional training. At the same time, our model is supplemented with the educational and information environment of the higher education institution, which acts as a catalyst for the motivational and valuable attitude of student pilots to future professional activities.

The model principles are schematically expressed in Fig. 1.

The training process is assumed as a specific type of the educational process at a higher education military institution to have a purposeful and pedagogically designed nature, focused on the current needs of the national Armed Forces.

Its strategic goal is to train professional military pilots prepared for effective combat piloting by means of military didactics.

The tactical tasks are as follows:

1) professional-orientation selection of students according to the list of updated mental, physical and psychological criteria;

2) application of systematic, competency-based and personality-oriented approaches in training at all stages and in all student pilot training forms;

3 ) the algorithm for the training process in three dialectically interrelated stages:

- preparation (diagnostics of the student's intellectual, psychological, physical, physiological and motivational readiness for future vocational activity; initial training - theoretical and general military training, technical and synthetic propaedeutics, initial physical and psychological training); 


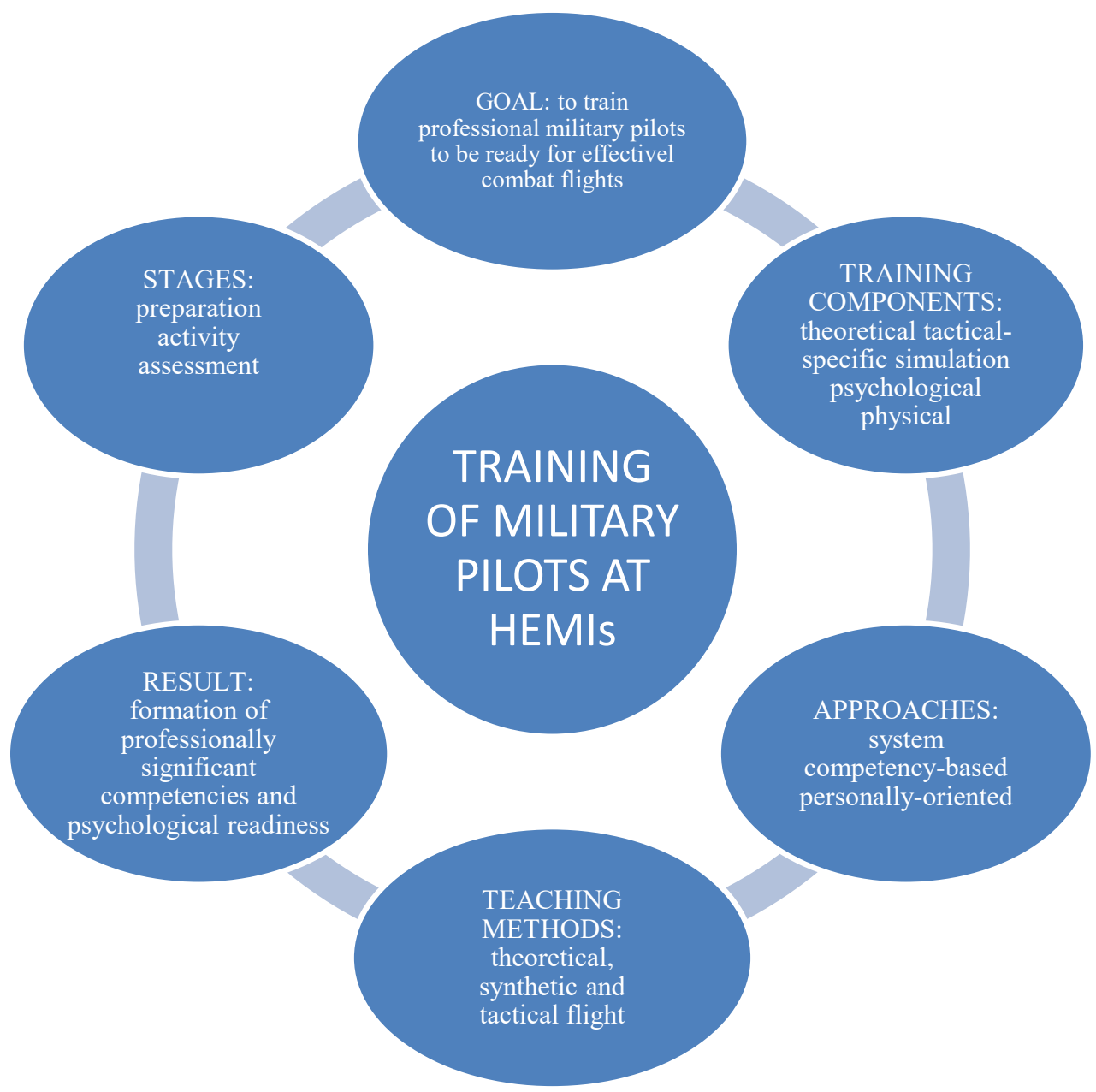

Fig. 1. Scheme of the principles of the model of training of future military pilots for combat flights

Source: developed by the author

- activity ("immersion" in the profession - mastering military aviation tactics, full synthetic and flight training, simulation of military flights in different conditions; formation of professionally significant abilities and skills; training attrition for weak students);

- assessment (diagnostics of the formation of professional competencies; final professional inconsistency-based screening).

The training components in our model are as follows:

- general theoretical, specific technical-theoretical (flight physics, military aircraft structure, navigation, guided and other aircraft equipment, combat complexes, military-aviation computer systems, etc.) and tactical-theoretical training;

- synthetic training on all types of modern aviation simulation systems;

- physical and physiological training (for fortitude and resistance to high overloads, parachute training, etc.); 
- flight training (ground and air, simulation of collisions with an enemy and other combat missions);

- intensive psychological training.

The training method, which should be distinguished from the flight training method, which is essentially a didactics of aeronautics, includes the whole range of modern pedagogical techniques and tools focused on interactive and group methods.

The pedagogical result of the training process should be a motivated, reliable, patriotic, stress-resistant personality of a military pilot - a staff officer with core competencies and psychological readiness to perform combat missions in the sky.

\section{Conclusions}

The above-described principles of the theoretical model of preparation of future military pilots for combat flights reveal the peculiarities of the training at HEMIs at the present stage, taking into consideration the specifics of military education. Deviation from the tendentious post-Soviet approach, limited by postulates of the flight training methodology, towards modern scientifically justified positions (based on concepts of a flight model and an operator of complex systems), allows, in our opinion, to implement a key pedagogical task - to form, test and introduce at domestic HEMIs the effective system to ensure quality of training of military aviation personnel for the needs of the Armed Forces of Ukraine.

In the perspective of further researches - clarification and extension of the scholarly apparatus of the proposed author's model and its experimental verification.

\section{References}

Nevzorov, R.V. (2020). Stvorennya pedagogichnoyi systemy zabezpechennya yakosti nazemnogo navchannya bojovym polotam majbutnix lotchykiv taktychnoyi aviaciyi u konteksti postupu Ukrayiny do NATO: do postanovky problemy [Development of the educational system to ensure quality for the ground combat flight training of future tactical aircraft pilots under accession to NATO of Ukraine: target setting]. Modernization of the education system: world trends and national peculiarities. Kaunas (Lithuania), 45-50. [in Ukrainian]

Osadchyi, I.G. (2017). Pedagogichne modelyuvannya: shho vazhlyvo znaty pedagogu? [Pedagogical modeling: what is important for a teacher to know?]. Public Education, 3, 142-151. [in Ukrainian]

Shtoff, V.A. (1966). Modelirovanie i filosofiya [Modeling and philosophy]. Leningrad: Science. [in Russian] 